\title{
Determinants of Female Teachers Progress to Leadership in Government Aided Primary Schools in Ntungamo District, Uganda
}

\author{
Wilson Mugizi*, Paulus January Masheija \\ Kampala International University Western Campus, Kampala, Uganda \\ Email: *wilsonmugizi@kiu.ac.ug
}

How to cite this paper: Mugizi, W., \& Masheija, P. J. (2019). Determinants of Female Teachers Progress to Leadership in Government Aided Primary Schools in Ntungamo District, Uganda. Open Journal of Leadership, 8, 143-166.

https://doi.org/10.4236/ojl.2019.84008

Received: September 14, 2019

Accepted: November 2, 2019

Published: November 5, 2019

Copyright () 2019 by author(s) and Scientific Research Publishing Inc. This work is licensed under the Creative Commons Attribution International License (CC BY 4.0).

http://creativecommons.org/licenses/by/4.0/

\begin{abstract}
This study explored the determinants of female teachers' progress to leadership in government-aided primary schools in Ntungamo District. Specifically, the study explored how personality characteristics, school factors and social factors determined female teachers' progress to leadership in government-aided primary schools. This cross-sectional study used a sample of 210 respondents and data were collected using a questionnaire survey. Data were analysed using descriptive analysis that included frequencies, percentages and means, and inferential analyses that were correlation and regression. Descriptive results revealed that the level of female teachers' progress to leadership was good, had strong personality characteristics and experienced favourable school and social factors. Regression results revealed that organisational factors and social were positive significant determinants of female teachers' progress to leadership while personality characteristics were negative and insignificant determinants. Therefore, the conclusions reached were that personality characteristics were not the most probable factors that determined female progress to leadership in primary schools, school factors were essential for female teachers' progress to leadership in primary schools, and social factors were imperative for female teachers' progress to leadership in primary schools. It was thus recommended that bodies charged with promoting of female teachers such District Education Service Commissions and schools leadership should assess personality characteristics of women when promoting them to leadership, those charged with management of schools such as District Education Officers, Inspectors of Schools, Schools Management Committees and head teachers should ensure that school factors promote female teachers progress to leadership, and leadership of schools from national to local level and community members should ensure that social factors in place promote female teachers progress to leadership.
\end{abstract}




\section{Keywords}

Organisational Factors, Personality Characteristics, Progress to Leadership, Social Factors

\section{Introduction}

Progress to leadership derives from two words namely; progress and leadership. Progress refers to the process of getting nearer to achieving or completing something (Giovannini, Hall, Morrone, \& Ranuzzi, 2011). On the other hand, leadership is the direction an individual in a position of authority gives to a group of people under him or her for the group to accomplish organisational objectives timely and efficiently using all the resources at the disposal of the group (Uzohue, Yaya, \& Akintayo, 2016). Therefore, progress to leadership is the achieving of a position of authority by an individual that enables him or her to provide direction to a group of people under him or her to accomplish organisational objectives timely and efficiently using all the resources at the disposal of the group. Chen and Bliese (2002) conceive leadership in terms vertical and horizontal leadership. According to Pretorius, Steyn and Bond-Barnard (2018), vertical leadership refers to the occupying of a position in the organisational hierarchy functioning as the main source of instruction, oversight, and control for his/her subordinates such as a head teacher in a school. On the other hand, they describe horizontal leadership as referring to the occupying of a leadership position in an organisation appointed by the vertical leader. In a school, horizontal leadership positions include being appointed as a director of studies, head of department or class teacher among others.

In all sectors of work, it is common knowledge that women in comparison to men do not hold an equal proportion of leadership positions across public and private societal spheres. The global workforce is highly gender-segregated and gender-stratified (Archard, 2012). A diverse range of explanations have been offered to explain the leadership gap between men and women with wide literature suggesting that gender bias and prejudice against women candidates lower the demand for female leadership. Focus has been on stereotyping, gender bias and discrimination against women as main contributors to the gender gap at the top levels. Further argument has also been that there is scarcity of qualified women as a contributing factor to the gender gap in leader selection (Gipson, Pfaff, Mendelsohn, Catenacci, \& Burke, 2017). However, the later argument is disputable because since the 1970s, educational reforms in most countries addressed much of the gender inequity that existed in educational settings and led systematically to an improvement in women's educational outcomes (Levtov, 2014). Nevertheless, improvement in the education of women has not been reflected by post-school success for women with regard to occupation of leadership positions. In reality, although women's attainment of education has increased, this 
has not translated into life achievement in positions of leadership (Schwanke, 2013). Even in professions such as teaching where women are the majority, when it comes to leadership positions, men remain dominant (Burton \& Weiner, 2016). Therefore, the purpose of this study was to explore the determinants of female teachers to leadership looking at social factors and environment conditions in terms of personality characteristics, organisational and social factors. This was the basis for suggesting factors to consider when promoting women to leadership positions in schools.

\section{Background}

In a modern civilised democratic institution, women must have equal access and participation in all modes of life including occupying positions of leadership (Gobaw, 2017). This is not only because of the principle of equality of rights, but because of the belief that no doubt, women are better managers. This belief is premised on the fact that women are more likely than men to adopt collaborative and empowering leadership styles while men are inclined to command and control behaviours and the assertion of power (Samantha, Paustian-Underdahl, Walker, \& Woehr, 2014). Despite this recognised advantage in leadership by women, today there is disequilibrium between male and female occupation of positions of leadership in society (Fritz \& van Knippenberg, 2017). In most patriarchal societies, females are regarded as the inferior of the species hence they are denied access to both honoured and utilitarian roles making them to open only to males. Therefore, leadership roles in societal affairs and governance exclusively belong to males (Hora, 2014). The global movement about women empowerment has not translated into women occupying leadership positions (Ngcobo, 2016). Women are still absent from most societal leadership positions in comparison with men. While in a country like the USA women make up nearly half of the workforce that is 47 per cent, men hold the vast majority of leadership positions in the corporate and political arenas (Warner \& Corley, 2017). Statistics for the years 2011-12 showed that the percentage of female principals was 52 percent (Hill, Ottem, \& De Roche, 2016) despite the fact that $89 \%$ of teachers in public primary schools and 86 per cent in private primary schools were females (Goldring, Gray, \& Bitterman, 2013).

In the UK, in primary schools still proportionately the number of female head teachers is lower. For instance, across all English state primary schools, 15\% of the workforce are male $(30,500)$ and $85 \%$ are female $(178,600)$. But looking at head teachers, $28 \%$ are male (4600) and $71 \%$ are female $(11,700)$. If these percentages were equal there would be over 1700 more female heads (McKillop \& Moorosi, 2017). In the other European countries, still women are over represented as teaching staff. The population of female teachers was $97.1 \%$ in Lithuania and Slovenia, 96.8\% in Czech Republic, 95.9\% in Italy and 95.6\% Hungary. In Greece (69.9\%), Spain (75.9\%), Luxembourg (76.0\%) and Sweden (77.0\%) were females. At EU level, 85.2\% of primary school teachers were women in 2013 (Bourgeais \& 
Grandovska, 2015). Despite the over representation of females as teachers, available statistics showed a different situation with respect to female head teachers. The statistics were Slovenia (58.0\%), Sweden (62.0\%), Finland (39.0\%), and Norway (50.0\%) among other countries (Trade Union Committee for Education, 2012).

In Sub-Saharan Africa, the gender divide is pervasive in numerous facets of life and is almost universally detrimental to the status and rights of women, resulting in a marginalised and subordinate position in society in comparison to their male counterparts. Women hold fewer managerial positions than men in Sub-Saharan Africa (Shoola, 2014). This is also reflected in headship in primary schools. For instance, while in South Africa in Gauteng province the workforce of women was 71 per cent, female head teachers were 37 per cent (Lumby \& Azaola, 2011). Lack of statistics in different African countries notwithstanding, studies reveal that it is not easy for females to become head teachers in Africa. For instance, Choge (2015) in a study in Kenya revealed that the challenges facing female teachers were lack of promotion, unequal advancement opportunities, motherhood responsibilities, and career immobility due to geographical immobility due to family responsibilities, lack of role models, dominance of males in the leadership network and lack of self-esteem to seek the administrative posts aggressively. Govinden (2008) in a study in South Africa reported that female teachers experienced the challenge of being mothers and spouses and living in a male dominated and patriarchal society. Mwanzia (2017) also in study in Kenya revealed that female head teachers suffered negative attitudes from the society, disrespect and stereotyping from male counterparts, and had the challenge of dealing with difficult teachers and School Management Committee members as well as household-work conflicts.

In Uganda, data on women leadership in primary schools is lacking. However, few available empirical studies in Uganda studies reveal a number of challenges hindering females from becoming head teachers. Lunyolo, Ayodo and Tikoko (2017) in a study in primary schools in Uganda established that female head teachers experienced insubordination from some members of staff, were marginalised by male teachers, looked down on by subordinates, suffered the challenge of double responsibilities at home and at school, biasness by male counterparts, and were stigmatised by male teachers. Sperandio and Kagoda (2010) in a study in Uganda revealed that female teachers aspired to school leadership but few had positioned themselves to do well in the competitive application process and thought the process was corrupt and did not expect to get the support of their current school administrators. With such impediments to females' progress to leadership in schools, it was paramount for this study to examine factors affecting women progress to leadership to suggest how to address the problem.

\section{Literature Review}

Theoretical Review. This study was premised to the Self Determination Theory (SDT) propounded by Deci and Ryan in 1985 and early 2000s (Deci \& 
Ryan, 2008). SDT is based on the proposition that the natural inclination and progression of humans is towards psychological growth, internalisation, and well-being and that humans act on and are acted upon by the factors in ways that differentially facilitate or hinder the realisation of this natural progression (Van den Broeck, Ferris, Chang, \& Rosen, 2016). SDT explains the nature of motivation, that is, the "why" of behaviour. The underlying assumption is that human beings are active, growth-oriented organisms who are naturally inclined towards integration of their psychic elements into a unified sense of self and integration of themselves into larger social structures (Deci \& Ryan, 2008). Although psychological growth and integration tendencies are natural, they are susceptible to social factors and environmental conditions which can either support propensities for self-determination or disrupt them (Tremblay, Blanchard, Taylor, Pelletier, \& Villeneuve, 2009). SDT suggests that human beings have the motivation for natural inclination and progression but are affected by social and environmental conditions. Therefore, basing on SDT, this study analysed how social factors and environment conditions namely; personality characteristics, organisational and social factors relate to female teachers progress to leadership.

Personality Characteristics and Female Teachers Progress to Leadership. Personality characteristics refer to relatively enduring patterns of thoughts, feelings and behaviours that reflect the tendency to respond in certain ways under certain circumstances (Fletcher, 2013). Such characteristics include self-confidence, self-esteem, assertiveness (Ademe \& Singh, 2015) and locus of control (Gabdreeva \& Khalfieva, 2016). Self-confidence refers to the feeling of sureness of an individual and he or she is equal to the task at hand (Bajpai \& Sultana, 2015). Self-esteem is the individual's subjective evaluation of his or her worth as a person as being good enough (Orth \& Robins, 2014). Assertiveness is one's ability to express and advocate ideas, interests, and feeling easy, appropriately and without anxiety (Paeezy, Shahraray, \& Abdi, 2010). Locus of control refers to is the degree to which individuals perceive reinforcing events in their lives to be the result of their own actions or fate (Manichander, 2014). In this study, locus of control referred to internality and external locus of control (Rinn, Boazman, Jackson, \& Barrio, 2014). There are a number of scholars (Ademe \& Singh, 2015; Eby, Cader, \& Noble, 2003; Gabdreeva \& Khalfieva, 2016; Türetgen, Unsal, \& Erdem, 2008; Wille, Wiernik, Vergauwe, Vrijdags, \& Trbovic, 2018; Zubaidi, Al-Sammerai, \& Ahmad, 2011) that studied the relationship between personality characteristics and female teachers progress to leadership. For instance, Ademe and Singh (2015) in a study in selected public higher education institutions in Amhara region in Ethiopia established that self-confidence, self-esteem, and assertiveness were the most important factors that facilitated women into leadership.

Eby et al. (2003) in a study in the USA found out that high self-monitors (individuals with high locus of control) were more likely to emerge as leaders than were low self-monitors. Gabdreeva and Khalfieva (2016) studying features of 
personal properties and structure of low-level, middle-level and top-level female managers in Russia revealed that locus of control influenced women's uptake of leadership roles. Türetgen et al. (2008) using students in a Turkish university reported that self-monitoring (locus of control) predicted leader emergence. Wille et al. (2018) using European executives and non-executive employees established that both male and female executives tended to demonstrate an archetypical "leader personality" focused on assertiveness. Exploring barriers to women's participation in positions of power and decision making in Jordan, Zubaidi et al. (2011) reported that personality characteristics of women such as lack of self-confidence, the traditional social raising that promoted woman's dependency on the father, husband and brother in more of their affairs made their personalities negative hence negatively influencing their aspiration to reach leadership positions. While the above studies revealed that personality characteristics related to females progress to leadership, contextual gaps emerged as none of the studies was carried out in the context of a primary school and in Uganda. This contextual gap attracted this study to test the hypothesis to the effect that:

H1: Personality characteristics are determinants of female teachers' progress to leadership in primary schools.

School Factors and Female Teachers Progress to Leadership. School factors are a set of forces and elements that surround the school (inside and out), and have an impact directly or indirectly on the way in which the school operates and affect its access to resources necessary for the continuation of its work (Sanjuq, 2013). School factors are both internal and external. Internal factors refer to all elements of any given organisation that it can control and have a clear impact on the organisational culture, philosophies, policies, human resource, mission and purpose (Genç, 2014). Internal factors cover managers and employees, organisational culture, structure, management strategies and finally material and human resources (Alshura \& Al Assuli, 2017). For external factors, these refer to the forces outside the organisation that have the potential to significantly influence the likely success of the organisation such as economic, global, political, legal framework, networks, demographic and technological aspects (Madinda, 2014). Different scholars (Ademe \& Singh, 2015; Azeez \& Priyadarshini, 2018; Islam, Jantan, \& Saimoon, 2017; Knipfer, Shaughnessy, Hentschel, \& Schmid, 2017; Makori, Onyango, Attyang, Bantu, \& Onderi, 2011) have studied the relationship between school (organisational) factors and females' progress to leadership. For example, Ademe and Singh (2015) found out that networking opportunities and conducive organisational working environment were among the most important factors that led women into leadership.

Azeez and Priyadarshini (2018) in study that used female staff in the IT industry in India revealed that while organisational policy had a positive and significant relationship with women career advancement, organizational culture and the perceptions of the management did not. Relatedly, Islam et al. (2017) using employees of a garments industry in Bangladesh established that the level of succession planning, flexibility and communication were not favourable to 
bring females into leadership positions. However, Knipfer et al. (2017) using female staff from academia in Germany reported that leadership training was successful in empowering women to take responsibility by giving them the knowledge and strategies to proactively seek any support they needed to achieve their career goals. Lahti (2013) in a qualitative study in Finland revealed that organisational culture including offering opportunities for advancement opportunities, flexibility or acknowledge their skills had a role in women's managerial career development. Conversely, Makori, et al. (2011) in a study at Moi University in Kenya found out that organisational rules promoted limited women's participation in leadership and there were more male than female appointees as deans and heads of department. In all, the studies above suggested that significant effort had been made to analyse the relationship between organisational factors females progress to leadership. However, empirical gaps emerged. For instance, while all the studies indicated that all organisational factors affected females' progress leadership, Azeez and Priyadarshini (2018) indicated that the perceptions of the management did not. Still, an issue of contention was that Islam et al. (2017) and Makori et al. (2011) reported that the factors in the organisations did not favour women. This study thus sought to find out whether in Ugandan schools:

H2: School factors are determinants of female progress teachers' to leadership in primary schools.

Social Factors and Female Teachers to Leadership. Social factors refer to facts and experiences that influence individuals' personality, attitudes and lifestyle (Bolívar, Daponte, Rodríguez, \& Sánchez, 2010). Social factors include reference groups, family, role models and statuses (Durmaz \& Durmaz, 2014). Scholars (e.g. Archard, 2012; Elmuti, Jia, \& Davis, 2009; Gipson, Pfaff, Mendelsohn, Catenacci, \& Burke, 2017; Hora, 2014; Lahti, 2013; Latu, Mast, Lammers, \& Bombari, 2013; McEldowney, Bobrowski, \& Gramberg, 2009; Mwale \& Dodo, 2017) have related social factors and females progress to leadership. Different scholars have related social factors and females progress to leadership. For instance, Archard (2012) in a study in Australia, New Zealand, and South Africa reported that mentoring and role modelling helped females in developing the knowledge and skills required for leadership. Elmuti et al. (2009) in a survey of various industries in the United States found out that women motivated themselves to advance for top management positions but barriers such as discrimination, family-life demands, prejudice, and stereotyping resulted in fruitlessness in many cases. Gipson et al. (2017) in a review indicated that men were disproportionately represented in organisational leadership positions than women because of gender stereotypes and biases that resulted in prejudice and discrimination against women aspiring to be senior leaders. Accordingly, existing selection methods disadvantaged women because they often lacked accountability which allowed the opportunity for gender bias to influence the decision-making process.

Hora (2014) in a study in Bedele Town in Ethiopia administration revealed that lack of role models, socio-cultural and domestic responsibilities hindered 
women participation in leadership. Lahti (2013) in a study in Finland found out that women who thrived to be leaders and their own input in promoting female leadership through mentoring others played an important role in advancing women to leadership. Similarly, Latu et al. (2013) using data from male and female students in the USA found out that gender differences for females disappeared when exposed to female role models compared to a male role model or no role models. McEldowney et al. (2009) in an analysis of data from women female college students who attended the weeklong Auburn University Women's Leadership Institute reported that prejudice, biasness and stereotyping about what young women as a group and doubt about their competence in leadership led to the expectations that women were less able to assume leadership roles effectively than their male counterparts. In a study in the rural district of Sanyati in Zimbabwe, Mwale and Dodo (2017) found out that marginalisation of women in leadership positions emanated from conservative elements and practices contained in the culture. Accordingly, this was because socialisation clearly allotted responsibilities to the two constituencies differently with men socialised for leadership positions while women were responsible for taking care of homes and children. The studies above revealed that scholars had attempted to relate social factors and female teachers to leadership. However, contextual gaps emerged as all the studies were skewed outside Uganda. Therefore, in the context of Uganda made it imperative for this study to test the hypothesis that:

H3: Social factors are determinants of female teachers' progress to leadership in primary schools.

\section{Methodology}

Sample. This cross-sectional study collected used a sample of 210 comprising female teachers and head teachers from government aided primary schools in Ntungamo District in Southwestern Uganda. The sample was selected using simple random sampling from a sampling frame. Research assistants who were teachers in the different schools helped in collecting the data. Using simple random sampling, each respondent was selected at random and entirely by chance. This gave each individual female teacher or head teacher an equal chance of being part of the sample. This enabled collecting of data from a representative sample for generalisation of the findings. To protect the teachers that offered responses and ensure scientific validity, ethical considerations were given utmost significance throughout the study. This involved obtaining informed consent, ensuring anonymity, confidentiality, respect for privacy and avoid bias in the reporting of data.

Instruments. Since the study was a quantitative survey involving a large number of respondents. The data collection method adopted was the questionnaire survey, involving the use of self-administered questionnaires (SAQs) on female teachers and female head teachers. The SAQ was made up of three sections, namely; A through C. Section A was demographic characteristics of the 
respondents and sections $\mathrm{B}$ and $\mathrm{C}$ on the independent and dependent variables respectively. The question items on the dependent variable, namely; female teachers' progress to leadership were developed basing on the career pathways survey by Smith, Crittenden and Caputi (2012). For the independent variables, the question items on personality characteristics were adapted from (Singh \& Jha, 2010), school factors from the Organizational Environment Scale (OES) by Farooqi and Akhtar (2014) and Social Factors from Family Relationship Scale (Fok, Allen, Henry, \& Team, 2014), Influence of Others on Academic and Career Decisions Scale (IOACDS) (Nauta \& Kokaly, 2001), and measurement for domains of mentoring (Rogers, Monteiro, \& Nora, 2008).

The ranking of the question items in the instrument was a five-point Likert Scale (Where $1=$ strongly disagree $2=$ disagree $3=$ undecided $4=$ agree $5=$ strongly agree). Quality control of the instrument was attained through testing of validity and reliability during data analysis. Validity was attained using Exploratory Factor Analysis (EFA), Varimax rotation method provided by SPSS to establish correlation among factors (Rossoni, Engelbert, \& Bellegard, 2016). Items' loading highly that is above 0.50 were considered valid (Coetzee, Marx, \& Potgieter, 2017). The reliabilities of items in the various constructs were tested using Cronbach's Alpha $(\alpha)$. Reliabilities for the items in the different constructs were attained at $\alpha=$ 0.60 above. This was because although some studies suggest that values higher than 0.7 are ideal, a number of researches consider values under 0.70 but above 0.60 as satisfactory (Souza, Alexandre, \& Guirardello, 2017). Factor Analysis and Cronbach's alpha results are presented in the section of results.

Data Analysis. Data were processed before being analysed. The processing of the data involved coding, entering the data into the computer using the Statistical Package for Social Sciences, summarising them using frequency tables to identity errors and editing them to remove errors. Data will be analysed at using descriptive and inferential statistics. Descriptive statistics involved frequencies, percentages and means. Inferential statistics included correlation and regression analyses to establish the relationship between the independent and dependent variables respectively. This produced results amenable to generalisation.

\section{Results}

Demographic Characteristics. The typical respondent in this study was a female age 30 - 39 years (41.9\%), possessed a grade III certificate of education (57.1\%), had served for 5 - 10 years (50.5\%) and held the position of class teacher (43.3\%). Differences in the frequency totals in Table 1 were as a result of missing data in the responses. Since SPSS provides for valid percent, where there was missing data, valid percentages were considered during analysis not to affect the results.

Female Teachers Progress to Leadership. Female teachers' progress to leadership (FPL) was studied as unidimensional concept using 11 . The results of female teachers' progress to leadership include frequencies, percentages, and 
Table 1. Demographic characteristics.

\begin{tabular}{|c|c|c|c|}
\hline Item & Categories & Frequency & Percent \\
\hline \multirow{5}{*}{ Age groups } & Up to 29 years & 48 & 22.9 \\
\hline & 30 - 39 years & 88 & 41.9 \\
\hline & 30 - 39 years & 58 & 27.6 \\
\hline & 50 years and above & 16 & 7.6 \\
\hline & Total & 210 & 100.0 \\
\hline \multirow{5}{*}{ Education levels } & Grade III & 120 & 57.1 \\
\hline & Diploma & 64 & 30.5 \\
\hline & Bachelor's degree & 24 & 11.4 \\
\hline & Post graduate qualifications & 2 & 1.0 \\
\hline & Total & 210 & 100.0 \\
\hline \multirow{4}{*}{ Experience } & Less than 5 years & 40 & 19.0 \\
\hline & $5-10$ years & 106 & 50.5 \\
\hline & 11 years and above & 64 & 30.5 \\
\hline & Total & 210 & 100.0 \\
\hline \multirow{5}{*}{ Responsibility } & Subject Teacher only & 28 & 13.5 \\
\hline & Class teacher & 90 & 43.3 \\
\hline & Head of Department & 50 & 24.0 \\
\hline & Senior administrator & 40 & 19.2 \\
\hline & Total & 208 & 100.0 \\
\hline
\end{tabular}

means. Validity and reliability test that are factor loadings and Cronbach's alpha (a) are also presented. These indicate the accuracy and interrelatedness of the items measuring the concept of female teachers' progress to leadership. The results of female teachers' progress were as presented in Table 2.

Table 2 showed that female teachers progress to leadership (FPL) was rated as being good (mean $=3.97$ corresponding to agreed). Factor Analysis revealed the component of female teachers' progress to leadership could be reduced to four factors, with eigenvalues of $2.974,1.857,1.358$ and 1.192 respectively. The factors explained over $24 \%, 15 \%, 11 \%$ and $9 \%$ respectively of the joint variation in the respective items constituting a factor. Since a factor loading of at least 0.5 is considered strong (Coetzee, Marx, \& Potgieter, 2017). Table 2 suggests that each item loaded highly on the corresponding except for item nine which cross-loaded. Such cross-loading item was deemed complex suggesting that it reflected the influence of more than one factor and had to be dropped from subsequent analysis (Schmitt, 2011). The final Cronbach's alpha result in Table $2\left(\alpha=0.70^{* *}\right.$, initially $\left.{ }^{*} 0.71\right)$ indicates that dropping the ninth item in Table 2 made the items more valid but less reliable (hence the reduction of $\alpha$ from 0.71 to 0.70 ). But the final still indicated that the remaining items were internally consistent and thus all items reliably measured female teachers' progress to leadership. The item that loaded highly was dropped from subsequent analyses of the findings. 
Table 2. Means, factors loadings and Cronbach's Alphas on components of female progress to leadership.

\begin{tabular}{|c|c|c|c|c|c|c|c|}
\hline \multirow{2}{*}{ FPL } & \multicolumn{2}{|c|}{ Means $\left({ }^{\bar{x}}\right)$} & \multicolumn{4}{|c|}{ Factors Loadings } & \multirow{2}{*}{ Alpha (a) } \\
\hline & (Overall & $\bar{x}=3.97)$ & 1 & 2 & 3 & 4 & \\
\hline FPL1 & & 4.27 & 0.709 & & & & $0.71^{*}$ \\
\hline FPL2 & & 4.27 & 0.687 & & & & $0.70^{\star *}$ \\
\hline FPL3 & & 3.57 & 0.633 & & & & \\
\hline TPL4 & & 4.17 & 0.605 & & & & \\
\hline FPL5 & & 3.65 & & 0.702 & & & \\
\hline FPL6 & & 3.83 & & 0.657 & & & \\
\hline FPL7 & & 4.06 & & 0.626 & & & \\
\hline FPL8 & & 3.65 & & & 0.713 & & \\
\hline FPL9 & & 3.65 & & 0.604 & 0.609 & & \\
\hline FPL10 & & 4.30 & & & 0.519 & & \\
\hline FPL11 & & 4.07 & & & & 0.824 & \\
\hline FPL12 & & 3.93 & & & & - & \\
\hline Eigenvalue & & & 2.974 & 1.857 & 1.358 & 1.192 & \\
\hline$\%$ variance & & & 24.782 & 15.479 & 11.316 & 9.936 & \\
\hline
\end{tabular}

Determinants of Female Teachers Progress to Leadership. Three determinants of female progress to leadership namely personality characteristics (PC), school factors (SCF) and social factors (SOF) were considered. The results for the three determinants included frequencies, percentages and means. For each determinant, factor loadings and Cronbach's alpha (a) results are presented showing the validity and reliability of the results. The results of ethical leadership constructs are as presented in Table 3 .

Table 4 revealed that all the determinants of female teachers progress to leadership (FPL) were rated as being good (personality characteristics overall mean $=415$, school factors $=3.92$ and social factors mean $=4.03$ all corresponding to agreed). Factor Analysis revealed the component of determinants of female teachers' progress to leadership could be reduced to four factors personality characteristics and school factors while social factors could be reduced to three factors. The eigenvalues for personality characteristics factors were 2.316, 1.354, 1.308 and 1.072. The eigenvalues for school factors were 3.073, 1.876, 1.506 and 1.196. The eigenvalues for social factors were 3.178, 1.734 and 1.267. The personality characteristics factors explained over $24 \%, 15 \%, 11 \%$ and $9 \%$ respectively of the joint variation in the respective items constituting a factor. School factors explained over $22 \%, 14 \%, 12 \%$ and $10 \%$ respectively of the joint variation in the respective items constituting a factor. Social factors explained over $28 \%, 15 \%$ and $11 \%$ respectively of the joint variation in the respective items constituting a factor. Table 2 suggests that for personality characteristics each 
Table 3. Means, factors loadings and Cronbach's Alphas for components of determinants of female progress to leadership.

\begin{tabular}{|c|c|c|c|c|c|c|c|}
\hline \multirow{2}{*}{ PC } & \multicolumn{2}{|c|}{ Means $\left({ }^{\bar{x}}\right)$} & \multicolumn{4}{|c|}{ Factors Loadings } & \multirow{2}{*}{ Alpha (a) } \\
\hline & (Overall & $\bar{x}=415)$ & 1 & 2 & 3 & 4 & \\
\hline PC1 & \multicolumn{2}{|c|}{4.33} & 0.740 & & & & $0.61^{*}$ \\
\hline PC2 & \multicolumn{2}{|c|}{4.24} & 0.661 & & & & $0.61^{* *}$ \\
\hline PC3 & \multicolumn{2}{|c|}{4.53} & 0.519 & & & & \\
\hline PC4 & \multicolumn{2}{|c|}{4.59} & & & & & \\
\hline PC5 & \multicolumn{2}{|c|}{3.80} & \multicolumn{3}{|c|}{0.798} & & \\
\hline PC6 & \multicolumn{2}{|c|}{3.46} & \multicolumn{3}{|c|}{0.703} & & \\
\hline PC7 & \multicolumn{2}{|c|}{4.23} & \multicolumn{4}{|c|}{0.834} & \\
\hline PC8 & \multicolumn{2}{|c|}{3.79} & & 0.569 & 0.576 & & \\
\hline PC9 & \multicolumn{2}{|c|}{4.20} & & & & 0.772 & \\
\hline PC10 & \multicolumn{2}{|c|}{4.27} & & & & 0.742 & \\
\hline Eigenvalue & & & 2.316 & 1.354 & 1.308 & 1.072 & \\
\hline$\%$ variance & & & 22.525 & 14.267 & 12.661 & 10.987 & \\
\hline \multirow{2}{*}{ SCF } & \multicolumn{2}{|c|}{ Means $\left({ }^{\bar{x}}\right)$} & \multicolumn{4}{|c|}{ Factors Loadings } & \multirow{2}{*}{ Alpha (a) } \\
\hline & (Overall & $\bar{x}=3.92)$ & 1 & 2 & 3 & 4 & \\
\hline SCF1 & \multicolumn{2}{|c|}{3.78} & 0.816 & & & & $0.71^{*}$ \\
\hline SCF2 & \multicolumn{2}{|c|}{3.75} & 0.800 & & & & $0.67^{* *}$ \\
\hline SCF3 & \multicolumn{2}{|c|}{3.58} & 0.745 & & & & \\
\hline SCF4 & \multicolumn{2}{|c|}{4.22} & 0.587 & & & & \\
\hline SCF5 & \multicolumn{2}{|c|}{4.10} & 0.508 & & & & \\
\hline SCF6 & \multicolumn{2}{|c|}{4.39} & & 0.807 & & & \\
\hline SCF7 & & .26 & & 0.804 & & & \\
\hline SCF8 & & .72 & & & 0.856 & & \\
\hline SCF9 & & .81 & & & 0.594 & & \\
\hline SCF10 & & .64 & & & 0.501 & & \\
\hline SCF11 & & 97 & & & & 0.772 & \\
\hline SCF12 & & 87 & & & & - & \\
\hline Eigenvalue & & & 3.073 & 1.876 & 1.506 & 1.196 & \\
\hline$\%$ variance & & & 25.606 & 15.631 & 12.550 & 9.968 & \\
\hline$S O F$ & Mean & $(\bar{x})$ & & Facto & adings & & Alnha $(\alpha)$ \\
\hline 301 & (Overall & $\bar{x}=4.03)$ & 1 & 2 & 3 & 4 & Ripila (a) \\
\hline SOF1 & & .01 & 0.686 & & & & $0.70^{*}$ \\
\hline SOF2 & & .34 & 0.619 & & & & $0.71^{* *}$ \\
\hline SOF3 & & 38 & 0.613 & & & & \\
\hline SOF4 & & .51 & 0.606 & & & & \\
\hline SOF5 & & .40 & 0.583 & & & & \\
\hline
\end{tabular}




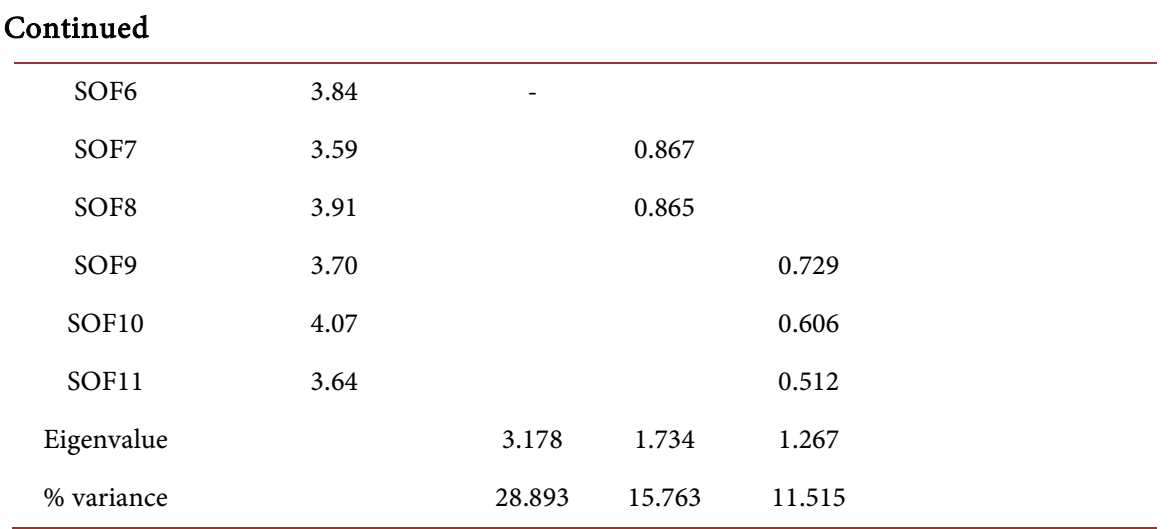

Table 4. Correlation of female teachers' progress to leadership on personality characteristics, organisational factors and social factors.

\begin{tabular}{ccccc}
\hline & $\begin{array}{c}\text { Female Teachers } \\
\text { Progress to Leadership }\end{array}$ & $\begin{array}{c}\text { Personality } \\
\text { Factors }\end{array}$ & $\begin{array}{c}\text { School } \\
\text { Factors }\end{array}$ & $\begin{array}{c}\text { Social } \\
\text { Factors }\end{array}$ \\
\hline $\begin{array}{c}\text { Female teachers progress to } \\
\text { leadership }\end{array}$ & 1 & & & \\
Personality characteristics & $0.303^{* *}$ & 1 & & \\
& 0.000 & & & \\
School factors & $0.599^{* *}$ & $0.345^{* *}$ & 1 & \\
& 0.000 & 0.000 & & 1 \\
Social factors & $0.507^{* *}$ & $0.543^{* *}$ & $0.527^{* *}$ & 1 \\
& 0.000 & 0.000 & 0.000 & \\
\hline
\end{tabular}

item loaded highly on the corresponding except for item four which loaded low and hence had to be dropped because it was considered weak (Coetzee et al., 2017). For school factors, each item loaded highly on the corresponding except for item 12 which loaded low and hence had to be dropped. For social factors, each item loaded highly on the corresponding except for item six which loaded low and hence had to be dropped. The final Cronbach's alpha $(\alpha)$ results in Table 3 were; personality characteristics $\alpha=0.61$, school factors $\alpha=0.67$ and social factors $\alpha=$ 0.71 . The items for the three determinants were considered reliable because according to Souza et al. (2017), Cronbach's alpha values above 0.60 are satisfactory.

Correlation of Female Teachers' Progress to Leadership on Personality Characteristics, Organisational Factors and Social Factors. To establish whether there was a relationship between female teachers' progress to leadership and personality characteristics, organisational factors and social factors, at the preliminary level a correlation analysis was carried out. The results are presented in Table 4.

The results in Table 4 suggest that there is a positive significant relationship between personality characteristics, organisational factors and social factors with female teachers' progress to leadership. This is because for all the variables, the critical values were significant at below 0.05 . This indicated the acceptance of the 
research hypotheses to the effect that personality characteristics are a determinant of female teachers' progress to leadership in primary schools $(\mathrm{r}=0.303, p=$ $0.000<0.05$ ), organisational factors are determinant of female progress teachers' to leadership in primary schools $(\mathrm{r}=0.599, p=0.000<0.05)$, and social factors are a determinant of female teachers progress to leadership in primary schools $(r=0.507, p=0.000<0.005)$. These preliminary results reveal that organisational factors correlated with female teachers' progress to leadership most significantly followed social factors and personality characteristics respectively.

Regression of Female Teachers' Progress to Leadership on Personality Characteristics, Organisational Factors and Social Factors. At the confirmatory level, to find out whether female teachers' progress to leadership was determined by personality characteristics, organisational factors and social factors, regression was carried out. The results were as in Table 5.

The results in Table 4 show that personality characteristics, school factors and social factors explained $40.9 \%$ of the variation in women's progress to leadership (adjusted $\mathrm{R}^{2}=0.409$ ). This means that $59.1 \%$ was accounted for by other variables not considered in this model. The regression model was good/significant $(\mathrm{F}=45.023, p=0.000<0.05)$. However, of the three factors, school factors $(\beta=$ $0.446, p=0.000<0.05)$ and social factors $(\beta=0.296, p=0.011<0.028)$ were positive significant determinants of female teachers progress to leadership while personality characteristics $(\beta=-0.028, p=0.671>0.05)$ were negative and insignificant determinants of females progress to leadership. The magnitudes of the respective betas suggested that school factors were the most significant determinants of female progress to leadership followed by social factors.

\section{Discussion}

The finding of the study revealed that personality characteristics were negative and insignificant determinants of females progress to leadership. This finding was consistent with the finding by Türetgen et al. (2008) that the personality characteristic of dominance and self-efficacy did not predict emergence to leadership. Similarly, Wille et al (2018) revealed that personality traits namely; conscientiousness, emotional stability and extraversion were smaller among female executives compared to non-executives. However, the finding was inconsistent

Table 5. Regression of female teachers' progress to leadership on personality characteristics, organisational factors and social factors.

\begin{tabular}{|c|c|c|}
\hline & Standardised Coefficients & Significance \\
\hline & $\operatorname{Beta}(\beta)$ & (p) \\
\hline Personality characteristics & -0.028 & 0.671 \\
\hline School factors & 0.446 & 0.000 \\
\hline Social factors & & \\
\hline $\begin{array}{l}\text { Adjusted R2 }=0.409 \\
\mathrm{~F}=45.023, \mathrm{p}=0.000\end{array}$ & 0.296 & 0.000 \\
\hline
\end{tabular}


with the findings of most previous scholars. Ademe and Singh (2015) revealed that personality characteristics namely self-confidence, self-esteem, and assertiveness were the most important factors that facilitated women into leadership. Similary, Eby et al. (2003) indicated that high self-monitors (locus of control) were more likely to emerge as leaders than were low self-monitors. Also, Gabdreeva and Khalfieva (2016) reported that the personality characteristics of locus of control influenced women's uptake of leadership roles. Further, the finding of the study was inconsistent with Türetgen et al. (2008) who established that the personality characteristic of self-monitoring (locus of control) predicted leader emergence. Likewise, Wille et al. (2018) revealed that female executives tended to demonstrate an archetypical "leader personality" focused on assertiveness, high-level strategic thinking, and decisiveness.

In the same vein, the finding was inconsistent with Zubaidi et al. (2011) who reported that only negative personality characteristics of women such as lack of self-confidence, the traditional social raising that concentrated on the woman's dependency on the father, husband and brother in more of their affairs made their personality negative hence negatively influencing their aspiration to reach the leadership position. Since, the finding of the study was inconsistent with the findings of most scholars, it can be deduced that in the context of Uganda, personality characteristics did not influence progress to leadership because of lower positions available considering the factor that the overall mean of personality characteristics was much higher than that of female teachers progress to leadership.

The findings indicated that school factors were positive significant determinants of female teachers' progress to leadership. This finding was consistent with the findings of some previous scholars. For instance, Azeez and Priyadarshini (2018) revealed that organisational policy had a positive and significant relationship with women career advancement. Similarly, Knipfer et al. (2017) reported that leadership training by organisations was successful in empowering women to take responsibility by giving them the knowledge and strategies to proactively seek any support they needed to achieve their career goals. Likewise, Lahti (2013) showed that organisational culture including offering opportunities for advancement, flexibility or acknowledging skills had a role in women's managerial career development. However, the finding that school factors were determinants of female teachers' progress to leadership in primary schools was also inconsistent with the finding by Azeez and Priyadarshini (2018) indicated that the perceptions of the management which were part of the factors did not influence women's progress to leadership. Similarly, Islam et al. (2017) and Makori et al. (2011) revealed that the factors in the organisations did not favour women. However, with the finding of the study consistent with the findings of some previous scholars and considering the factor that in Uganda there has been effort to champion women's progress to leadership, it can be deduced that school factors determine female teachers' progress to leadership.

Lastly, the study established that school factors were positive significant de- 
terminants of female teachers' progress to leadership. The finding of the study revealed that the hypothesis was supported. This finding agreed with the findings of previous scholars. For example, Archard (2012) indicated that mentoring and role modelling helped females in developing the knowledge and skills required for leadership as well as assisted the in understanding of gender barriers in relation to leadership roles. Similarly, Hora (2014) revealed that role models determined women's participation in leadership. Also, Lahti (2013) indicated that input of women who thrived as leaders promoted female leadership through mentoring which advanced women to leadership. Further still, Latu et al. (2013) reported that gender difference disappeared when exposed to female roles models with women showing a significant increase when exposed to a female role model compared to a male role model or no role models. Nevertheless, the finding was contrary to the finding by McEldowney et al. (2009) that prejudice, biasness and stereotyping about what young women as a group and doubt about their competence in leadership led to the expectations that women were less able to assume leadership roles effectively than their male counterparts. Further still, Mwale and Dodo (2017) reported that women sometimes failed to successfully take up leadership roles because of pressing household responsibilities. However, with the finding of the study agreeing with the findings of a number of previous studies, it can be inferred that positive social factors related to female teachers progress to leadership.

\section{Conclusion}

The discussion above guided the researcher to reach the following conclusions about the determinants of female progress to leadership in primary schools. First, personality characteristics were not the most probable factors that determined female progress to leadership in primary schools. Possibly, this was because in the selection of leaders for primary schools, the concerned bodies did to assess female teachers' self-belief, character strength, resilience and focus of life. Secondly, school factors were essential for female teachers' progress to leadership in primary schools. Such school factors included establishing conducive factors and policies that favour for both males and females, supervisors encouraging female teachers to participate in making important decisions and promoting teamwork among staff. In addition, the factors include giving them freedom to freely express their ideas, treating them with honour and dignity, offering them training, implementing national and international policies that promote women and ring fencing certain positions for women. Thirdly, social factors were imperative for female teachers' progress to leadership in primary schools. Such social factors include having female role models, leadership being image enhancing, having an encouraging and united family, family members supporting careers of women, and female teachers having people they can count on. The practical contribution of the study is that factors that promote female progress to leadership include school factors and social factors. The school factors are both 
internal and external and the social factors are female teachers having reference groups, family support, having role models and being a leader in a primary school being a position of status.

\section{Recommendations}

The conclusions above lead to the making of the following recommendations on promoting female progress to leadership in primary schools. In the first place, bodies charged with promoting female teachers such District Education Service Commissions and schools leadership should assess personality characteristics of women when promoting them to leadership. Such factors include female teachers' self-belief, character strength, resilience and focus of life. Secondly, those charged with management of schools such as District Education Officers, Inspectors of Schools, Schools Management Committees and head teachers should ensure that school factors promote female teachers progress to leadership. Such factor include establishing conducive factors and policies that favour for both males and females, supervisors encouraging female teachers to participate in making important decisions and promoting teamwork among staff. There should also be the giving of female teachers' freedom to freely express their ideas, treating them with honour and dignity, offering them training, implementing national and international policies that promote women and ring fencing certain positions for women. Thirdly, leadership of schools from national to local level and community members should ensure that social factors promote female teachers progress to leadership. Such factors include having female role models in positions of leadership, leadership being image enhancing, families being encouraging and united, family members supporting careers of women, and in positions of power there being people female teachers can count on.

\section{Limitations and Suggestions for Further Research}

This study makes significant contributions to enhancing female teachers' progress to leadership in primary schools is concerned. However, a number of limitations emerged that cannot be ignored. For instance, the results of the study on the first hypothesis were inconsistent with what was postulated. Therefore, future researchers should further investigate how personality characteristics determine female teachers' progress to leadership at a wider scope. Still, the study was dominantly quantitative. Therefore, future researchers should largely adopt the qualitative approach to have an in-depth analysis of the determinants of female teachers' progress to leadership in primary schools.

\section{Conflicts of Interest}

The authors declare no conflicts of interest regarding the publication of this paper.

\section{References}

Ademe, G., \& Singh, M. (2015). Factors Affecting Women's Participation in Leadership 
and Management in Selected Public Higher Education Institutions in Amhara Region, Ethiopia. European Journal of Business and Management, 7, 18-29.

Alshura, M. S. K., \& Al Assuli, A. H. (2017). Impact of Internal Factors on Performance Excellence in Jordanian Public Universities from Faculty Points of View. International Journal of Business and Social Science, 8, 45-57.

Archard, N. (2012). Student Leadership Development in Australian and New Zealand Secondary Girls' Schools: A Staff Perspective. International Journal of Leadership in Education, 15, 23-47. https://doi.org/10.1080/13603124.2011.605472

Azeez, P. N., \& Priyadarshini, R. G. (2018). Glass Ceiling Factors Affecting Women Career Advancement in IT Industry in India. IOP Conference Series: Materials Science and Engineering, 390, Article ID: 012021. https://doi.org/10.1088/1757-899X/390/1/012021

Bajpai, S., \& Sultana, N. (2015). A Study of Self-Confidence in Female Volleyball Players: With Reference to Sports Achievements. Research Journal of Physical Education Sciences, 3, 9-11.

Bolívar, J., Daponte, A., Rodríguez, M., \& Sánchez, J. J. (2010). The Influence of Individual, Social and Physical Factors on Physical Activity in the Adult Population in Andalusia, Spain. International Journal of Factors of Research and Public Health, 7, 60-77. https://doi.org/10.3390/ijerph7010060

Bourgeais, V., \& Grandovska, B. (2015). Women Teachers Over-Represented at Early Stages of Education in the EU.

https://ec.europa.eu/eurostat/../3...BP.../9f0d2d04-211a-487d-87c3-0a5f7d6b22ce

Burton, L. J., \& Weiner, J. M. (2016). They Were Really Looking for a Male Leader for the Building: Gender, Identity and Leadership Development in a Principal Preparation Program. Frontiers in Psychology, 7, 141. https://doi.org/10.3389/fpsyg.2016.00141

Chen, G., \& Bliese, P. D. (2002). The Role of Different Levels of Leadership in Predicting Self- and Collective Efficacy: Evidence for Discontinuity. Journal of Applied Psychology, 87, 549-556. https://doi.org/10.1037/0021-9010.87.3.549

Choge, J. R. (2015). Gender Factor in Decision Making: Challenges Facing Women Leadership Development in Primary Schools' Management in Kenya. Journal of Education and Practice, 6, 31-37.

Coetzee, M., Marx, A. A., \& Potgieter, I. L. (2017). Examining the Construct Validity of the Positive Coping Behavioural Inventory. SA Journal of Industrial Psychology, 43, 1-8. https://doi.org/10.4102/sajip.v43i0.1433

Deci, E. L., \& Ryan, R. M. (2008). The "What" and "Why" of Goal Pursuits: Human Needs and the Self-Determination of Behaviour. Psychological Inquiry, 11, 227-268. https://doi.org/10.1207/S15327965PLI1104_01

Durmaz, Y., \& Durmaz, B. N. (2014). The Impact of Social Factors on Consumer Buying Behaviour and an Empirical Application in Turkey. Journal of Social Science Research, 3, 256-263. https://doi.org/10.24297/jssr.v2i2.3108

Eby, L. T., Cader, J., \& Noble, C. L. (2003). Why Do High Self-Monitors Emerge as Leaders in Small Groups? A Comparative Analysis of the Behaviours of High versus Low Self-Monitors. Journal of Applied Social Psychology, 33, 1457-1479. https://doi.org/10.1111/j.1559-1816.2003.tb01958.x

Elmuti, D., Jia, H., \& Davis, H. H. (2009). Challenges Women Face in Leadership Positions and Organizational Effectiveness: An Investigation. Journal of Leadership Education, 8, 167-187. https://doi.org/10.12806/V8/I2/RF4

Farooqi, M. T. K., \& Akhtar, M. S. (2014). Development and Validation of Organisational 
Environment Scale (OES) for University Teachers. Journal of Research \& Reflections in Education, 8, 75-85.

Fletcher, J. M. (2013). The Effects of Personality Traits on Adult Labor Market Outcomes: Evidence from Siblings. Journal of Economic Behavior \& Organization, 89, 122-135. https://doi.org/10.1016/j.jebo.2013.02.004

Fok, C. C. T., Allen, J., Henry, D., \& Team, P. A. (2014). The Brief Family Relationship Scale: A Brief Measure of the Relationship Dimension in Family Functioning. Assessment, 21, 67-72. https://doi.org/10.1177/1073191111425856

Fritz, C., \& van Knippenberg, D. (2017). Gender and Leadership Aspiration: The Impact of Organisational Identification. Leadership \& Organization Development Journal, 38, 1018-1037. https://doi.org/10.1108/LODJ-05-2016-0120

Gabdreeva, G. S., \& Khalfieva, A. R. (2016). The Features of Female Managers' Personality Traits in Organisation. International Journal of Factors and Science Education, 11, 1195-1203.

Genc, K. Y. (2014). Factors Affecting Human Resources Management Activities of Turkish Large Firms. International Journal of Business and Management, 9, 102-123. https://doi.org/10.5539/ijbm.v9n11p102

Giovannini, E., Hall, J., Morrone, A., \& Ranuzzi, G. (2011). A Framework to Measure the Progress of Societies. Revue D'économiepolitique, 121, 93-118.

https://doi.org/10.3917/redp.211.0093

Gipson, A. N., Pfaff, D. L., Mendelsohn, D. B., Catenacci, L. T., \& Burke, W. W. (2017). Women and Leadership: Selection, Development, Leadership Style, and Performance. The Journal of Applied Behavioral Science, 53, 32-65. https://doi.org/10.1177/0021886316687247

Gobaw, M. K. (2017). Women's Role and Their Styles of Leadership. International Journal of Educational Administration and Policy Studies, 9, 28-34. https://doi.org/10.5897/IJEAPS2015.0415

Goldring, R., Gray, L., \& Bitterman, A. (2013). Characteristics of Public and Private Elementary and Secondary School Teachers in the United States: Results from the 2011-12 Schools and Staffing Survey. Washington DC: U.S. Department of Education. https://nces.ed.gov/pubs2013/2013314.pdf

Govinden, Y. J. (2008). The Challenges Faced by Female Teachers in Assuming Leadership Roles in Schools: A Study of Two Schools in Pietermaritzburg and Two Schools in a Small Town Just outside Pietermaritzburg. Masters Dissertation, Durban: University of Kwazulu-Natal.

Hill, J., Ottem, R., \& De Roche, J. (2016). Trends in Public and Private School Principal Demographics and Qualifications: 1987-88 to 2011-12. Washington DC: USA Department of Education. https://nces.ed.gov/pubs2016/2016189.pd

Hora, E. A. (2014). Factors That Affect Women Participation in Leadership and Decision Making Position. Asian Journal of Humanity, Art and Literature, 1.

https://ssrn.com/abstract=2601782

https://doi.org/10.15590/ajhal/2014/v1i2/54050

Islam, M. A., Bin Zantan, H., \& Saimoon, A. (2017). Factors Affecting Females' Participation in Leadership Positions in RMG Industry, Bangladesh. International Journal of Scientific and Research Publications, 7, 535-542.

Knipfer, K., Shaughnessy, B., Hentschel, T., \& Schmid, E. (2017). Unlocking Women's Leadership Potential: A Curricular Example for Developing Female Leaders in Academia. Journal of Management Education, 41, 272-302.

https://doi.org/10.1177/1052562916673863 
Lahti, E. (2013). Women and Leadership: Factors That Influence Women's Career Success: Female Leaders' Reflections on Their Career Development and Leadership. Master's Thesis, Lahti: Lahti University of Applied Sciences.

Latu, I. M., Mast, M. S., Lammers, J., \& Bombari, D. (2013). Successful Female Leaders Empower Women's Behaviour in Leadership Tasks. Journal of Experimental Social Psychology, 49, 444-448. https://doi.org/10.1016/j.jesp.2013.01.003

Levtov, R. (2014). Addressing Gender Inequalities in Curriculum and Education: Review of Literature and Promising Practices to Inform Education Reform Initiatives in Thailand. Washington DC: World Bank. https://openknowledge.worldbank.org

Lumby, J., \& Azaola, C. (2011). Women Principals in Small Schools in South Africa. Australian Journal of Education, 55, 73-85. https://doi.org/10.1177/000494411105500108

Lunyolo, H. G., Ayodo, T. M. O., \& Tikoko, B. (2017). Gender Based Leadership and School Administration: A Case Study of Mbale District Local Government. Kabarak Journal of Research \& Innovation, 4, 48-59.

Madinda, A. S. (2014). The Uncertainty of Organisational Factors in Developing Countries. International Journal of Emerging Trends in Science and Technology, 1, 774-782.

Makori, R. S., Onyango, M., Attyang, J. M., Bantu, E., \& Onderi, P. O. (2011). Organisational Cultural Factors Hindering Women Ascending to Top Management Positions in Public Universities in Kenya: A Case of Moi University. Journal of Education and Practice, 7, 79-84.

Makori, R. S., Onyango, M., Attyang, J. M., Bantu, E., \& Onderi, P. O. (2011). Organisational Cultural Factors Hindering Women Ascending to Top Management Positions in Public Universities in Kenya: A Case of Moi University. Journal of Education and Practice, $7,79-84$.

Manichander, T. (2014). Locus of Control and Performance: Widening Applicabilities. Online Submission, 3, 84-86. https://doi.org/10.15373/22501991/FEB2014/25

McEldowney, R. P., Bobrowski, P., \& Gramberg, A. (2009). Factors Affecting the Next Generation of Women Leaders: Mapping the Challenges, Antecedents, and Consequences of Effective Leadership. Journal of Leadership Studies, 3, 24-30.

https://doi.org/10.1002/jls.20105

McKillop, E., \& Moorosi, P. (2017). Career Development of English Female Head-Teachers: Influences, Decisions and Perceptions. School Leadership \& Management, 37, 334-353. https://doi.org/10.1080/13632434.2017.1338682

Mwale, C., \& Dodo, O. (2017). Sociocultural Beliefs and Women Leadership in Sanyati District. Journal of Social Change, 9, 107-118.

Mwanzia, D. (2017). Challenges Faced by Women Head Teachers in Public Primary Schools in Mbooni East District, Makueni County. International Journal of Sciences: Basic and Applied Research (IJSBAR), 35, 228-248.

Nauta, M. M., \& Kokaly, M. L. (2001). Assessing Role Model Influences on Students' Academic and Vocational Decisions. Journal of Career Assessment, 9, 81-99. https://doi.org/10.1177/106907270100900106

Ngcobo, A. D. (2016). Analysing the Empowerment of Women Leadership: A Case of the Durban University of Technology. Masters Dissertation, Durban: Durban University of Technology.

Orth, U., \& Robins, R. W. (2014). The Development of Self-Esteem. Current Directions in Psychological Science, 23, 381-387. https://doi.org/10.1177/0963721414547414

Paeezy, M., Shahraray, M., \& Abdi, B. (2010). Investigating the Impact of Assertiveness Training on Assertiveness, Subjective Well-Being and Academic Achievement of Ira- 
nian Female Secondary Students. Procedia-Social and Behavioral Sciences, 5, 1447-1450. https://doi.org/10.1016/j.sbspro.2010.07.305

Pretorius, S., Steyn, H., \& Bond-Barnard, T. J. (2018). Leadership Styles in Projects: Current Trends and Future Opportunities. South African Journal of Industrial Engineering, 29, 161-172. http://dx.doi.org/10.7166/29-3-2057

Rinn, A., Boazman, J., Jackson, A., \& Barrio, B. (2014). Locus of Control, Academic Self-Concept, and Academic Dishonesty among High Ability College Students. Journal of the Scholarship of Teaching and Learning, 14, 88-114. https://doi.org/10.14434/v14i4.12770

Rogers, J., Monteiro, F. M., \& Nora, A. (2008). Toward Measuring the Domains of Mentoring. Family Medicine-Kansas City, 40, 259-263.

Rossoni, L., Engelbert, R., \& Bellegard, N. L. (2016). Normal Science and Its Tools: Reviewing the Effects of Exploratory Factor Analysis in Management. Revista de Administração (São Paulo), 51, 198-211. https://doi.org/10.5700/rausp1234

Samantha, C., Paustian-Underdahl, S. C., Walker, L. S., \& Woehr, J. D. (2014). Gender and Perceptions of Leadership Effectiveness: A Meta-Analysis of Contextual Moderators. Journal of Applied Psychology, 99, 1129-1145. https://doi.org/10.1037/a0036751

Sanjuq, G. (2013). The Impact of Internal Factors Elements on Organisational Commitment Applied Study in Social Security Corporation in KSA. European Journal of Business and Management, 5, 204-214.

Schmitt, T. A. (2011). Current Methodological Considerations in Exploratory and Confirmatory Factor Analysis. Journal of Psychoeducational Assessment, 29, 304-321. https://doi.org/10.1177/0734282911406653

Schwanke, D. A. (2013). Barriers for Women to Positions of Power: How Societal and Corporate Structures, Perceptions of Leadership and Discrimination Restrict Women's Advancement to Authority. Earth Common Journal, 3, 15-28.

https://doi.org/10.31542/j.ecj.125

Shoola, T. (2014). The Effect of the Sub-Saharan African Gender Divide on the Rights and Status of Women in a Globalized World. International ResearchScape Journal, 1, 1-46.

Singh, K., \& Jha, S. D. (2010). The Positive Personality Traits Questionnaire: Construction and Estimation of Psychometric Properties. Psychological Studies, 55, 248-255. https://doi.org/10.1007/s12646-010-0027-0

Smith, P., Crittenden, N., \& Caputi, P. (2012). Measuring Women's Beliefs about Glass Ceilings: Development of the Career Pathways Survey. Gender in Management, 27, 68-80. https://doi.org/10.1108/17542411211214130

Smith, P., Crittenden, N., \& Caputi, P. (2012). Measuring Women's Beliefs about Glass Ceilings: Development of the Career Pathways Survey. Gender in Management: An International Journal, 27, 68-80. https://doi.org/10.1108/17542411211214130

Souza, A. C. D., Alexandre, N. M. C., \& Guirardello, E. D. B. (2017). Psychometric Properties in Instruments Evaluation of Reliability and Validity. Epidemiologia e Serviços de Saúde, 26, 649-659. https://doi.org/10.5123/S1679-49742017000300022

Sperandio, J., \& Kagoda, A. M. (2010). Women Teachers' Aspirations to School Leadership in Uganda. International Journal of Educational Management, 24, 22-33. https://doi.org/10.1108/09513541011013024

Trade Union Committee for Education (2012). School Leadership in Europe: Issues, Challenges and Opportunities. https://www.csee-etuce.org/images/attachments

Tremblay, M. A., Blanchard, C. M., Taylor, S., Pelletier, L. G., \& Villeneuve, M. (2009). 
Work Extrinsic and Intrinsic Motivation Scale: Its value for Organizational Psychology Research. Canadian Journal of Behavioural Science/Revue Canadienne des sciences du Comportement, 41, 213. http://dx.doi.org/10.1037/a0015167

Türetgen, I. Ö., Unsal, P., \& Erdem, I. (2008). The Effects of Sex, Gender Role, and Personality Traits on Leader Emergence: Does Culture Make a Difference? Small Group Research, 39, 588-615. https://doi.org/10.1177/1046496408319884

Uzohue, C., Yaya, J., \& Akintayo, O. A. (2016). A Review of Leadership Theories, Principles, Styles and Their Relevance to Management of Health Science Libraries in Nigeria. Journal of Educational Leadership and Policy, 1, 17-26.

Van den Broeck, A., Ferris, D. L., Chang, C. H., \& Rosen, C. C. (2016). A Review of Self-Determination Theory's Basic Psychological Needs at Work. Journal of Management, 42, 1195-1229. https://doi.org/10.1177/0149206316632058

Warner, J., \& Corley, D. (2017). The Women's Leadership Gap. Washington DC: Centre for American Progress.

https://www.americanprogress.org/issues/women/reports/.../womens-leadership-gap

Wille, B., Wiernik, B. M., Vergauwe, J., Vrijdags, A., \& Trbovic, N. (2018). Personality Characteristics of Male and Female Executives: Distinct Pathways to Success? Journal of Vocational Behaviour, 106, 220-235. https://doi.org/10.1016/j.jvb.2018.02.005

Zubaidi, F. R., Al-Sammerai, N. S. M., \& Ahmad, F. (2011). An Overview on Women's Leadership Issues in Jordan. Journal of Politics and Law, 4, 67-73.

https://doi.org/10.5539/jpl.v4n2p67 


\section{Appendix: Study Instrument}

\begin{tabular}{|c|c|c|}
\hline Construct & Item & Measures \\
\hline \multicolumn{3}{|c|}{ Section A: Background characteristics } \\
\hline & BV2 & $\begin{array}{l}\text { Highest level of education attained by the respondent (Grade III, Diploma, Bachelor's degree, } \\
\text { Post graduate qualifications) }\end{array}$ \\
\hline & BV4 & $\begin{array}{l}\text { Responsibility (Subject Teacher only, Class teacher, Head of Department, Senior } \\
\text { administrator) }\end{array}$ \\
\hline \multirow[t]{12}{*}{ Section B: Female teachers progre } & leadership & Measures \\
\hline & FPL1 & Many females in the primary schools education sector enjoy being in the limelight \\
\hline & FPL3 & $\begin{array}{l}\text { Females in positions of leadership in primary schools are comfortable when they have to } \\
\text { criticise fellow teachers }\end{array}$ \\
\hline & TPL4 & In primary schools females with skills and qualifications are recognised for promotion \\
\hline & FPL5 & There are many females in senior positions in the primary schools sector \\
\hline & FPL6 & $\begin{array}{l}\text { In the primary schools education sector females have attained equality with men in getting } \\
\text { management positions }\end{array}$ \\
\hline & FPL7 & In the primary schools education sector females have the same desire for power as men do \\
\hline & FPL8 & $\begin{array}{l}\text { A female with requisite qualifications can occupy a leadership position in the primary schools } \\
\text { sector }\end{array}$ \\
\hline & FPL9 & $\begin{array}{l}\text { In the primary schools education sector women are just as ambitious as men in seeking } \\
\text { leadership positions }\end{array}$ \\
\hline & FPL10 & There are female leaders in the primary schools sector that have excelled in their positions \\
\hline & FPL11 & In primary schools females have the opportunity to reach the top \\
\hline & FPL12 & Females participate in making critical leadership decisions in schools \\
\hline Section: Determinants & & Measures \\
\hline \multirow[t]{10}{*}{ Personality characteristics (PC) } & PC1 & I do have enough control over the direction my life is taking \\
\hline & PC2 & I make people remain feeling good as I try to get them to understand my own ideas. \\
\hline & PC3 & I consider myself a very well organised individual \\
\hline & PC4 & I trust my ability to perform my job \\
\hline & PC5 & Every time I try to go ahead, I achieve it \\
\hline & PC6 & $\begin{array}{l}\text { I can get a person to understand that he or she is being unjust if he or she points out my } \\
\text { failures due to a misunderstanding. }\end{array}$ \\
\hline & PC7 & I am always positive about my capabilities \\
\hline & PC8 & I estimate my abilities to be very high compared to those of my colleagues \\
\hline & PC9 & I consider myself to be more capable or equal with colleagues \\
\hline & PC10 & In my life, I consider hard work to be more important for success \\
\hline \multirow[t]{3}{*}{ School factors (SCF) } & SCF1 & The working conditions in this primary school sector are conducive for both male and females \\
\hline & SCF2 & The school implements a policy that supports women's progress \\
\hline & SCF3 & My immediate supervisor encourages me to participate in making important decisions \\
\hline
\end{tabular}




\section{Continued}

SCF4

SCF5

SCF6

SCF7

SCF8

SCF9

SCF10

SCF11

SCF12

Social factors (SOF)
Team work promoted in the primary schools sector

I can express my ideas freely whenever necessary

The seniors treat juniors with honour and dignity in the primary schools sector

I am provided with the opportunity to get the training, needed in work related activities

I am well aware of policy making process in the primary schools sector

The school follows national and international policies with respect to uplifting women

Some positions have been ring fenced for women in the primary schools sector

There are outside agencies supporting the cause of women in the primary schools sector

The school is required to have a certain quota of positions for women in management

SOF1 There are people who help me to make my career choices

SOF2

I feel inspired to join leadership in teaching because those women in leadership are sometimes admired or respected by others

SOF3 I believe that taking on a leadership position in teaching will enhance my social status

SOF4 I feel that I should be successful as women leaders I admire

SOF5

There are people I am trying to be like in my career

SOF6

SOF7

There are people I can count on to support my career choices

There are women in positions of leadership in the teaching and other sectors whose success influences me

SOF8 My colleagues' involvement in leadership has influenced my attitudes to the same

SOF9 In my family we begin discussions easily

SOF10 There are people who help me to make my career choices

SOF11 In my family we talk openly to one another 